\title{
Club cell protein 16 as a biomarker in pulmonary contusion
}

\author{
FENG WU $^{1}$, BOYING DING ${ }^{2}$, XIAOLONG YANG ${ }^{2}$, \\ DONGCHUN MA ${ }^{1}$, CHAODONG ZHANG ${ }^{1}$ and CONGSHU HUA ${ }^{1}$ \\ ${ }^{1}$ Department of Cardiothoracic Surgery, Anhui Chest Hospital, Hefei, Anhui 230022; \\ ${ }^{2}$ Department of Cardiothoracic Surgery, Yijishan Hospital, Wannan Medical College, Wuhu, Anhui 241001, P.R China
}

Received March 18, 2016; Accepted May 26, 2016

DOI: 10.3892/br.2016.704

\begin{abstract}
The aim of the present study was to investigate the variation and clinical significance of the $16-\mathrm{kDa}$ club cell protein (CC16) in patients with pulmonary contusion. A total of 42 patients with pulmonary contusion were divided into experimental groups I ( $\mathrm{n}=24$, moderate pulmonary contusion) and II ( $\mathrm{n}=18$, severe pulmonary contusion). An enzyme-linked immunosorbent assay was used to detect the serum levels of CC16 in the two groups of patients within $24 \mathrm{~h}$ after the incident and at days 1,3,7 and 14 after treatment. The results were compared with another 16 healthy subjects included as the controls. The serum CC16 level at each time point was higher in the two experimental groups compared to the controls $(\mathrm{P}<0.01)$. The difference was significant when regarding the levels of $\mathrm{CC} 16$ measured within $24 \mathrm{~h}$ after contusion and at days $1,3,7$ and 14 after treatment $(\mathrm{P}<0.01)$; however, the levels appeared to decline. In addition, the levels at each time point in experimental group II were significantly higher compared to group I $(\mathrm{P}<0.01)$. In conclusion, serum $\mathrm{CC} 16$ levels are markedly elevated at the early stage of pulmonary contusion and appear to decrease following treatment. An increase of the CC16 levels is associated with the degree of injury, for which measurement of the levels may serve as a biomarker for evaluation of the serious condition of this pulmonary contusion.
\end{abstract}

\section{Introduction}

Club cells are a nonciliated group of cells of the bronchiolar epithelium, and the earliest reported discovery was by Koller. Club cell protein, a microprotein of $16 \mathrm{kDa}(\mathrm{CC} 16)$, exists mainly in the lung epithelial lining fluid. The occurrence of CC16 in the lung epithelial lining fluid is 10,000 times higher compared to in the peripheral blood. The epithelium is the main

Correspondence to: Professor Boying Ding, Department of Cardiothoracic Surgery, Yijishan Hospital, Wannan Medical College, 2 Zheshan West Road, Wuhu, Anhui 241001, P.R China E-mail: dby0067@126.com

Key words: club cell protein, pulmonary contusion, clinical significance barrier hindering the bidirectional alveolar/blood exchange of proteins, thus the damage of the pulmonary alveolar capillary barrier (PACB) may lead to the imbalance (1).

Lung injury from pulmonary contusion is severe traumatic injury, which is more common (30-75\%) in chest trauma (2). In the lung parenchyma appeared an increase in the blood capillary permeability of the lung, deposition of inflammatory cells and release of inflammatory mediators. Pulmonary edema is caused by pulmonary contusion, which leads to breathing obstacles and subsequently hypoxemia. Pulmonary contusion occurs often with rib fractures, pneumothorax or other organ damage due to external forces, and it increases the severity and complexity of the injury. When pulmonary contusion is concurrent with acute respiratory distress syndrome (ARDS), the mortality rate can be $56-76 \%$ (3).

Previous domestic and foreign animal experiments have shown that the development of a variety of lung diseases is closely associated with the 16-kDa club cell and closely associated with the CC16 protein (4). Serum CC16, as a sensitive indicator in acute and chronic damage and an assessment of the alveolar membrane, has attracted increasing attention from medical professionals. The present study investigated the variation and clinical significance of serum CC16 levels in patients with pulmonary contusion with the aim to identify sensitive laboratory indicators that can early diagnose and intervene with the severity of pulmonary contusion or even ARDS.

\section{Subjects and methods}

Subjects. A retrospective observational study was conducted between June and December in 2013 at the Department of Cardiothoracic Surgery of Yijishan Hospital (Wuhu, Anhui, China). A total of 42 patients (27 men and 15 women; age, $51.04 \pm 23.28$ years) with pulmonary contusion were divided into experimental groups $\mathrm{I}(\mathrm{n}=24$ with moderate pulmonary contusion; 16 men and 8 women; age, $58.09 \pm 14.46$ years) and II $(\mathrm{n}=18$ with severe pulmonary contusion; 11 men and 7 women; age, $47.15 \pm 14.07$ years). Pulmonary contusion in the present subjects was a result of a fall injury $(n=19)$, traffic injury $(n=13)$ and violent injury $(\mathrm{n}=10)$. A measurement of lung contusion volume $\leq 20 \%$ was classified as moderate pulmonary contusion and $>20 \%$ was classified as severe (5), as defined on the axial computed tomography (CT) images with automatic interpolation and volume calculation (6). Experimental groups I and II 
Table I. Serum CC16 levels of experimental groups I and II.

\begin{tabular}{|c|c|c|c|c|c|c|c|c|}
\hline \multirow[b]{2}{*}{ Group } & \multirow[b]{2}{*}{ Total, $\mathrm{n}$} & \multicolumn{5}{|c|}{ Mean serum CC16 levels \pm standard deviation, $\mu \mathrm{g} / 1$} & \multirow[b]{2}{*}{$\mathrm{F}$} & \multirow[b]{2}{*}{ P-value } \\
\hline & & $\mathrm{T}_{1}$ & $\mathrm{~T}_{2}$ & $\mathrm{~T}_{3}$ & $\mathrm{~T}_{4}$ & $\mathrm{~T}_{5}$ & & \\
\hline I & 24 & $18.96 \pm 2.14^{\mathrm{a}}$ & $18.36 \pm 2.22^{\mathrm{a}}$ & $14.26 \pm 1.97^{\mathrm{a}}$ & $9.79 \pm 1.28^{\mathrm{a}}$ & $8.69 \pm 1.07^{\mathrm{a}}$ & 166.21 & $<0.01$ \\
\hline II & 18 & $26.11 \pm 4.10^{\mathrm{a}, \mathrm{b}}$ & $24.90 \pm 3.37^{\mathrm{a}, \mathrm{b}}$ & $19.87 \pm 2.69^{\mathrm{a}, \mathrm{b}}$ & $15.66 \pm 2.33^{\mathrm{a}, \mathrm{b}}$ & $12.77 \pm 2.22^{\mathrm{a}, \mathrm{b}}$ & 65.09 & $<0.01$ \\
\hline
\end{tabular}

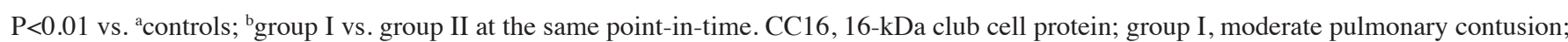
group II, severe pulmonary contusion.

were compared with 16 healthy subjects, who were included as the controls.

The present study was approved by the ethics committee of Wannan Medical College (Wuhu, Anhui, China). All subjects were informed of the present study and provided written consent.

Diagnosis and treatment. All the patients in the experimental group underwent a CT check and blood gas analysis. The CT exhibited the pulmonary contusion at varying degrees and excluded primary lung infection. The patients were diagnosed according to the Guidelines for management of acute lung injury/ARDS: An evidence-based update by the Chinese Society of Critical Care Medicine (2006) Chinese (7).

All 42 patients accepted the guidelines and recommended treatment, including maintaining patent airway, oxygen, anti-inflammatory and rehydration treatment, and 7 patients had rib fracture fixation. Potential indications and inclusion criteria for rib fracture repair included: i) Flail chest, ii) reduction of pain and disability, iii) chest wall deformity/defection, iv) symptomatic rib fracture non-union, and v) thoracotomy for other indications (8).

All the patient symptoms improved significantly after 14 days of the aforementioned treatment.

Blood sampling and analysis. Blood samples ( $3 \mathrm{ml}$ in coagulation syringes) from all experimental groups were collected from patients directly following admission to the emergency department within $24 \mathrm{~h}\left(\mathrm{~T}_{1}\right)$ and at 6:00 a.m. on day $1\left(\mathrm{~T}_{2}\right), 3\left(\mathrm{~T}_{3}\right)$, $7\left(\mathrm{~T}_{4}\right)$ and $14\left(\mathrm{~T}_{5}\right)$ after treatment. Samples were centrifuged at $1,006.2 \mathrm{x} \mathrm{g}$ for $5 \mathrm{~min}$ at room temperature, and the plasma was removed and stored at $-80^{\circ} \mathrm{C}$ until assayed. The blood samples of the healthy subjects were obtained at 6:00 a.m. An enzyme-linked immunosorbent assay (ELISA) (Human Clara Cell Protein ELISA kit; cat. no. CSB-E08680h/V04038457; Cusabio Biotech Co., Ltd., Wuhan, China) was used to detect the serum levels of CC16.

The samples were analyzed using statistic software SPSS 13.0 (SPSS, Inc., Chicago, IL, USA) for descriptive and inferential statistical assessment. Categorical measures were analyzed using variance analysis and the q test. For all analyses, $\mathrm{P}<0.05$ was considered to indicate a statistically significant difference.

\section{Results}

Serum levels in the experimental groups. All the serum CC16 levels of the experimental group exceeded the control group at any point-in-time. The corresponding values for serum CC16 at $\mathrm{T}_{1}, \mathrm{~T}_{2}, \mathrm{~T}_{3}, \mathrm{~T}_{4}$ and $\mathrm{T}_{5}$ were $22.03 \pm 4.73,21.16 \pm 4.27$, $16.67 \pm 3.60,12.31 \pm 3.44$ and $10.44 \pm 2.62 \mu \mathrm{g} / 1$, respectively, and $7.32 \pm 2.51 \mu \mathrm{g} / 1$ for the control group $(\mathrm{F}=82.55, \mathrm{P}<0.01)$.

The serum CC16 levels of experimental groups I and II also decreased from $\mathrm{T}_{1}$ to $\mathrm{T}_{5}(\mathrm{P}<0.01)$ (Table $\left.\mathrm{I}\right)$.

\section{Discussion}

Following the occurrence of chest trauma, the majority of patients can be cured by conservative treatment. Therefore, it is difficult to obtain enough information regarding the clinical pathological research of lung injury. Understanding the process, development and outcome of pulmonary contusion clinically remains to be elucidated (9) and is the reason for the lack of standard unity of injury grade or clinical stage of pulmonary contusion clinically and radiologically thus far (10). Therefore, the present study aimed to explore how to diagnose the severity of pulmonary contusion and determine the curative effect.

The study by Helleday et al (11) demonstrated the use of CC16 as a biomarker in studies of exposure-induced effects, and reported a time-dependent diurnal variation. Determann et al (12) reported the identification of ALI/ARDS patients by a sudden increase in plasma $\mathrm{CC} 16$ of $\geq 30 \%$ yielded a sensitivity of $90 \%$ and a specificity of $92 \%$. The study by Wutzler et al (13) showed that serum CC16 levels correlated with the volume of lung contusions and were not influenced by overall injury severity, age, gender or preclinical ventilation. They hypothesized that CC16 could be a potential biomarker for lung injury in patients due to its high correlation with the volume of contused lung parenchyma. Serum CC16 levels demonstrate a noninvasive and sensitive marker of lung epithelial injury.

The present study examined the utility of CC16 as a biomarker of lung injury in patients with pulmonary contusion. The serum CC16 levels of the experimental groups were evidently higher compared to the controls at any point-in-time $(\mathrm{P}<0.01)$. This indicates that lung epithelial cells and PACB undergo serious damage at an early stage following lung injury. CC16 spread into the blood from the respiratory tract due to a significant concentration difference. The increase of serum CC16 is closely associated with the lung injury. Due to the increase of blood capillary permeability in inflammatory reaction, injury parenchyma becomes congestion and edema. This progressive process makes the patchy infiltrate shadows more clear in images at $24-48 \mathrm{~h}$ after lung injury. However, the 
present study observed that after 1 day of treatment, the serum CC16 levels of the experimental groups began to decrease $(\mathrm{P}<0.01)$. This indicates that the inflammatory cascade reactions in patients with pulmonary contusion increase and the lung injury extent enlarge on the imaging at an early stage, but the damage of epithelial cells and PACB is under control. After treatment for 3, 7 and 14 days, the serum CC16 levels showed a decreasing trend in recovery. Simultaneously, lung injury to an extent narrows on the imaging, the blood oxygen of the patient rises, and lung function recovers clinically. Therefore, a decline of serum CC16 level is closely associated with the improvement of the pulmonary contusion. However, the serum CC16 levels do not reduce to the levels of the controls $(\mathrm{P}<0.01)$ in experimental groups I and II after treatment for 14 days.

Table I shows that the serum CC16 level of experimental group I is higher compared to group II at any time-point assessed $(\mathrm{P}<0.01)$, indicating that the serum CC16 levels in patients with pulmonary contusion positively correlate with the severity of lung injury. Therefore, $\mathrm{CC} 16$ has a significant role in the pathological process of pulmonary contusion. $\mathrm{CC16}$ may be a biomarker not only in laboratory diagnosis, but in the detection of pulmonary contusion progression by maintaining dynamic monitoring.

In conclusion, the present study demonstrates that $\mathrm{CC} 16$ will aid in diagnosing and determining the severity of pulmonary contusion. Further research regarding CC16 is being conducted and $\mathrm{CC} 16$ as a biomarker is expected to become more valuable.

\section{Acknowledgements}

The authors would like to thank Mr. Gang Ren, Mr. Kepin Xiong, Mr. Dong Xu, Mr. Jiaping Li and Mr. Xiaole Deng for their technical assistance, and Professor Yingshui Yao and Mr. Lianping He for their statistical advice.

\section{References}

1. Blomberg A, Mudway I, Svensson M, Hagenbjörk-Gustafsson A, Thomasson L, Helleday R, Dumont X, Forsberg B, Nordberg G and Bernard A: Clara cell protein as a biomarker for ozone-induced lung injury in humans. Eur Respir J 22: 883-888, 2003.

2. Lorraine B and Ware MD: The acute respiratory distress syndrome. N Engl J Med 34: 1334-1349, 2002.

3. Zhang H: Severe chest trauma concurrent adult respiratory distress syndrome from high-risk factors synthetically analyzed. Sichuan Med J 1: 785-786, 2010.

4. Wang Q and Li Z: Research progress in Clara cell protein in lung injury. Chinese Journal of Extracorpor Circulation 9: 57-64, 2011.

5. Allen GS and Coates NE: Pulmonary contusion: A collective review. Am Surg 62: 895-900, 1996.

6. Zhao Y, Cheng C, Yin J, Yang D, Huang T and Huang Y: Experimental study on the volume of irregular foci measured by both modalities of integration and radial line. J Pract Med Imaging 8: 265-266, 2007.

7. Chinese Society of Critical Care Medicine; Chinese Medical Association: Guidelines for management of acute lung injury/acute respiratory distress syndrome: an evidence-based update by the Chinese Society of Critical Care Medicine (2006). Zhongguo Wei Zhong Bing Ji Jiu Yi Xue 18: 706-710, 2006 (In Chinese).

8. Nirula R, Diaz JJ Jr, Trunkey DD and Mayberry JC: Rib fracture repair: Indications, technical issues, and future directions. World J Surg 33: 14-22, 2009.

9. Sellke FW, del Nido PJ and Swanson SJ (eds): Sabiston and Spencer's surgery of the chest. 8th edition. Saunders Elsevier, Philadelphia, PA, pp92-93, 2010.

10. Yu H, Wang C, Wang Z, Fenk K, Yang X, Liu X, Wang Z and Luo J: Severe pulmonary contusion CT image and clinical process classification. China Journal of Emergency Resuscitation and Disaster Medicine 5: 523-524, 2010.

11. Helleday R, Segerstedt B, Forsberg B, Mudway I, Nordberg G, Bernard A and Blomberg A: Exploring the time dependence of serum clara cell protein as a biomarker of pulmonary injury in humans. Chest 130: 672-675, 2006.

12. Determann RM, Millo JL, Waddy S, Lutter R, Gerrard CS and Schultz MJ: Plasma CCl6 levels are associated with development of ALI/ARDS in patients with ventilator-associated pneumonia: A retrospective observational study. BMC Pulm Med 9: 49, 2009.

13. Wutzler S, Lehnert T, Laurer H, Lehnert M, Becker M, Henrich D, Vogl T and Marzi I: Circulating levels of Clara cell protein 16 but not surfactant protein D identify and quantify lung damage in patients with multiple injuries. J Tranma 71: E31-36, 2011. 